\title{
PROTEASE OBTENTION USING BACILLUS SUBTILIS 3411 AND AMARANTH SEED MEAL MEDIUM AT DIFFERENT AERATION RATES
}

\author{
Maria Delia Pastor*; Graciela Susana Lorda; Antonio Balatti \\ IMIQA (Instituto de Investigación y Desarrollo en Microbiología y Química Aplicada), \\ Facultad de Ciencias Exactas y Naturales, UNLPam, Santa Rosa, La Pampa, Argentina. \\ Submitted: September 23, 1999; Returned to authors for corrections: February 04, 2000; Approved: March 07, 2001
}

\begin{abstract}
The influence of the addition of Amaranthus cruenthus seed meal to the medium, as nutrient and growth factor, on protease production by Bacillus subtilis 3411 was studied. Tests were carried out in a rotary shaker and in mechanically stirred fermenters. The influence of aeration was also evaluated. The addition of amaranth in a concentration of $20 \mathrm{~g} / \mathrm{L}$ resulted in $400 \%$ increase in protease production. Aeration up to 750 r.p.m. and 1 L/L.min had a favorable effect.
\end{abstract}

Key words: Proteases, Bacillus subtilis, amaranth, fermentation

\section{INTRODUCTION}

The bacterial proteases have found wide scale industrial application. Industries in which proteases are used include the pharmaceutical industry, the leather industry, the manufacture of protein hydrolizates, the food industry and the waste processing industry. The aim of this work was to improve the production of alcaline protease by Bacillus subtilis 3411. Using a recommended medium $(1,8,9)$, the effect of amaranth seed meal at different aeration rates on the enzymatic protease levels achieved in rotary shakers and stirred fermenter was studied. Amaranth seed meal is a pseudocereal which contains a good aminoacid distribution and a high level content of several vitamins, $(2,3,4,7,11)$. Addition of amaranth seed meal as growth factor in the culture medium can be an important procedure for optimization of the process.

Finally, using a balanced amaranth seed meal medium, the effect of aeration conditions on the protease formation was evaluated.

\section{MATERIALS AND METHODS}

\section{Microorganism}

A strain of Bacillus subtilis NRRL 3411 kept in the medium $\mathrm{N}^{\mathrm{o}} 1$ (Table 1) as spores in peat was used. The peat, 200 mesh, was adjusted to a $12 \%$ humidity content. Five gram portions were put into tubes and sterilized at $121^{\circ} \mathrm{C}$ for 3 hours. Once the sterilization process was over, the mixture was impregnated with $3 \mathrm{~mL}$ spore suspension obtained in medium $\mathrm{N}^{\circ} 1$ (Table 1). Tubes were hermetically sealed by either a threaded cap or a plastic film cover upon cotton caps. Tubes were stored at $5^{\circ} \mathrm{C}$.

\section{Media}

Culture media are shown in Table 1. The medium used in process, $\mathrm{N}^{\circ} 3$, was modified with the addition of Amaranthus cruenthus seed meal, 200 mesh. This material was used in different concentrations (g/L): 10; 20; 40; 60, 80.

\section{Inocula}

Each flask was inoculated with a peat-kept spore suspension in $5 \mathrm{~mL}$ sterilized distilled water, previously exposed to 10 minute, $100^{\circ} \mathrm{C}$ thermal shock. $(5,13,15)$.

\section{Operating conditions}

Inocula were developed in $250 \mathrm{~mL}$ Erlenmeyer flasks containing $50 \mathrm{~mL}$ of culture medium. Processes were carried out in $500 \mathrm{~mL}$ Erlenmeyer flasks containing $100 \mathrm{~mL}$ of culture medium incubated for 72 hours in a rotary shaker (250 r.p.m. and eccentricity $2.5 \mathrm{~cm}$ ). In all these experiments culture media and containers were sterilized at $121^{\circ} \mathrm{C}$ for 20 minutes. Assays

\footnotetext{
* Corresponding author. Mailing address: IMIQA (Instituto de Investigación y Desarrollo en Microbiología y Química Aplicada), Facultad de Ciencias Exactas y Naturales, UNLPam, Av. Uruguay 151, 6.300, Santa Rosa, La Pampa, Argentina. Telephone: (+54) 2954-436787. Fax: (+54) 2954-432679
} 
in fermenter were carried out at different stirring conditions, namely: 350; 750 and 1000 r.p.m., the aeration rate was 1 L/L. Min. Fermentation studies were performed in a 5 liter New Brunswick stirred fermenter using $3 \mathrm{~L}$ of culture medium. A connection to monitors allowed the following measurements and control measures to be obtained, namely: $\mathrm{pH}$, temperature and stirring, dissolved oxygen partial pressure, and foam control by means of an automatic addition process of an antifoam silicone agent through a peristaltic pump.

Amaranthus cruenthus seed meal was used, previously milled to 200 mesh.

\section{Cell growth}

Microbial growth was determined by optical density units $(650 \mathrm{~nm})$ and by dry weight. A $10 \mathrm{~mL}$ sample was taken and centrifuged at $5000 \mathrm{~g}$ for 20 minutes. Precipitate was washed with distilled water twice. Precipitate was then resuspended in water and dried at $100^{\circ} \mathrm{C}$ until constant weight.

\section{Determination of alcaline protease activity}

To determine the alcaline protease activity of culture media, ANSON modified method was used (8). ANSON modified enzyme unit, uAPAM, is defined as that quantity of enzyme which produces soluble fragments in tricloroacetic acid $0.2 \mathrm{M}$ equivalent to $0.5 \mu \mathrm{g}$ tyrosine at $37^{\circ} \mathrm{C}$ in 10 minutes.

\section{Consumption of lactose}

To determine lactose concentration in the culture medium, Miller's spectrophotometric method, which measures reducing sugar, was used (10).

\section{Determining cell oxygen demand and $Q_{02}$ respiratory coefficient}

The oxygen demand was measured in a Warburg respirometer at $28^{\circ} \mathrm{C}(14)$.

\section{Oxygen absorption rate}

The oxygen absorption rate (OAR) was measured by the sulphite method (10).

\section{Dissolved Oxygen}

The dissolved oxygen was measured with a sterilizable silver-lead galvanic probe.

\section{RESULTS}

For tests carried out in rotary shaker, cell oxygen demand was in the order of $240 \mathrm{~mL} \mathrm{O}_{2} / \mathrm{L}$.h for dry weight concentrations of $8.4 \mathrm{~g} / \mathrm{L}$ and oxygen dissolution values were in the order of $500 \mathrm{~mL} \mathrm{O}_{2} / \mathrm{L} . \mathrm{h}$

Table 1. Composition of culture media.

\begin{tabular}{lccc}
\hline Composition $(\mathrm{g} / \mathrm{L})$ & $\begin{array}{c}\text { Sporulation } \\
\mathrm{N}^{\circ} 1\end{array}$ & $\begin{array}{c}\text { Inocula } \\
\mathrm{N}^{\circ} 2\end{array}$ & $\begin{array}{c}\text { Process } \\
\mathrm{N}^{\circ} 3\end{array}$ \\
\hline Lactose & - & 10.00 & 20.00 \\
Glucose & 1.00 & - & - \\
Yeast extract & 5.00 & 5.00 & 6.00 \\
Peptone from meat & 5.00 & 5.00 & 20.00 \\
$\left(\mathrm{Britania} \mathrm{N}^{\circ} 1\right)$ & & & \\
$\mathrm{KH}_{2} \mathrm{PO} 4$ & - & 1.00 & 1.50 \\
$\mathrm{~K}_{2} \mathrm{HPO}_{4}$ & - & 1.00 & 1.50 \\
$\mathrm{CaCl}_{2} .2 \mathrm{H}_{2} \mathrm{O}$ & - & - & 0.06 \\
$\mathrm{MnCl}_{2} .4 \mathrm{H}_{2} \mathrm{O}$ & - & - & 0.01 \\
$\mathrm{NaCl}_{\mathrm{MgSO}} .7 \mathrm{H}_{2} \mathrm{O}$ & - & - & 1.50 \\
$\mathrm{EDTA}_{\mathrm{Na}} \mathrm{SO}_{4}$ & - & - & 0.15 \\
$\mathrm{Tween}_{80}$ & - & - & 0.56 \\
$\mathrm{Agar}$ & - & - & 1.50 \\
$\mathrm{pH}$ & - & - & 5.00 \\
\hline
\end{tabular}

Table 2. Influence of different concentrations of amaranth seed meal on proteases production, as determined in experiments performed in erlenmeyers on a rotary shaker at 250 r.p.m. and eccentricity $2.5 \mathrm{~cm}$, for 72 hours.

\begin{tabular}{lcccccc}
\hline \multicolumn{1}{c}{$\begin{array}{c}\text { Measured parameter } \\
\text { (72 hours) }\end{array}$} & \multicolumn{5}{c}{ Amaranth seed meal concentration $(\mathrm{g} / \mathrm{L})$} \\
\cline { 2 - 7 } & Control & 10 & 20 & 40 & 60 & 80 \\
\hline Optical density units & 18.18 & 5.1 & 8.7 & 13.7 & 14.3 & 12.0 \\
pH & 6.2 & 7.1 & 6.9 & 7.1 & 7.2 & 6.9 \\
Lactose comsuption (g/L) & 16.8 & 18 & 17.87 & 17.8 & 18.11 & 17.95 \\
Dry weight (g/L) & 8.0 & 8.1 & 8.4 & 9.3 & 9.6 & 8.8 \\
Yield (g/g) & 0.44 & 0.45 & 0.47 & 0.52 & 0.53 & 0.49 \\
Specific cell growth rate (1/h) & 0.029 & 0.029 & 0.030 & 0.031 & 0.030 & 0.030 \\
Enzymatic activity (uAPAM/mL) & 1065.0 & 2480.0 & 3950.0 & 1980.0 & 1960.0 & 1700.0 \\
Specific enzymatic production (uAPAM/g) & 133125.0 & 306172.5 & 470238.1 & 212903.0 & 204166.7 & 193181.8 \\
Productivity & 14791.7 & 34444.4 & 54861.1 & 27500.0 & 27222.2 & 23611.1 \\
(uAPAM/L h) & & & & & &
\end{tabular}


Table 2 shows results obtained in tests carried out in stirred erlenmeyers. In these experiments the influence of adding different concentrations of amaranth seed meal: 10; 20;40; 60 and $80 \mathrm{~g} / \mathrm{L}$ to a medium $\mathrm{N}^{\circ} 3$, as shown in Table 1, which is used in turn as control, was considered.

It was observed that highest values of protease were obtained when a concentration of $20 \mathrm{~g} / \mathrm{L}$ was added to the medium. Higher concentrations of amaranth seed meal showed lower enzyme activity, specific production and productivity, whereas biomass concentration, yields and specific growth rate were similar.

On the basis of results obtained in rotary shaker stirred erlenmeyers flasks, using the process medium with the addition of $20 \mathrm{~g} / \mathrm{L}$ amaranth seed meal, new experiments were carried out in a stirred fermenter. The influence of aeration over process productivity was studied, using different stirring conditions and an air rate of $1 \mathrm{~L} / \mathrm{L}$ min (Table 3). Oxygen dissolution rates used were similar and higher than those determined by rotary shaker, $529 \mathrm{~mL} \mathrm{O} /$ L.h. Those values were for 350 r.p.m. $=562.43 \mathrm{~mL} \mathrm{O} / /$ L.h; for 750 r.p.m. $=2691 \mathrm{~mL} \mathrm{O} /$ L.h and for 1000 r.p.m. $=5011 \mathrm{~mL} \mathrm{O} /$ L.h. Fig. 1 show results obtained in these series of experiments. Table 3 also shows that the highest value of enzyme production was obtained at 750 r.p.m. with a protease level in the order of $11600 \mathrm{uAPAM} / \mathrm{mL}$ of culture, a specific growth rate of $0.0291 / \mathrm{h}$, a yield of 0.43 grams of biomass for lactose gram consumed, a biomass of $7.8 \mathrm{~g} / \mathrm{L}$ of culture, specific production of 1487179.5 uAPAM for biomass gram, productivity of 161111.1 uAPAM for litre of fermented culture for hour. In all processes the evolution of $\mathrm{pH}$ values was almost near $\mathrm{pH} 7$.

Table 3. Effect of aeration condition on the protease production in stirred fermentor.

\begin{tabular}{|c|c|c|c|}
\hline \multirow{2}{*}{$\begin{array}{l}\text { Measured parameter } \\
\quad(72 \text { hours })\end{array}$} & \multicolumn{3}{|c|}{ Agitation (r.p.m.) } \\
\hline & 350 & 750 & 1000 \\
\hline $\begin{array}{l}\text { Lactose consumption } \\
\text { (g/L) }\end{array}$ & 17.9 & 18.0 & 17.7 \\
\hline $\mathrm{PH}$ & 7.1 & 7.0 & 7.4 \\
\hline Optical density units & 14.0 & 13.0 & 13.0 \\
\hline Dry weight (g/L) & 7.0 & 7.8 & 8.0 \\
\hline $\begin{array}{l}\text { Specific cell growth } \\
\text { rate }(1 / \mathrm{h})\end{array}$ & 0.027 & 0.029 & 0.029 \\
\hline Yield (g/g) & 0.39 & 0.43 & 0.45 \\
\hline $\begin{array}{l}\text { Enzymatic activity } \\
\text { (uAPAM/mL) }\end{array}$ & 3950.0 & 11600.0 & 10000.0 \\
\hline $\begin{array}{l}\text { Specific enzymatic } \\
\text { production (uAPAM/g) }\end{array}$ & 564285.7 & 1487179.5 & 1250000.0 \\
\hline $\begin{array}{l}\text { Productivity } \\
\text { (uAPAM/L.h) }\end{array}$ & 54861.1 & 161111.1 & 138888.9 \\
\hline
\end{tabular}

\section{DISCUSSION}

The considerable increase $(400 \%)$ in production of proteases in rolary shakers, should be assigned to the important contribution of amino acids and vitamins from amaranth seed meal (3).

The protease synthesized by Bacillus subtilis NRRL 3411 has a molecular weight of $27400 \mathrm{~d}$ and 275 amino acid residues, with a large proportion of aspartic acid, serine, glicine, alanine and valine (8). With reference to the amaranth composition, the components of the material used in our studies in $\mathrm{g} / 100 \mathrm{~g}$
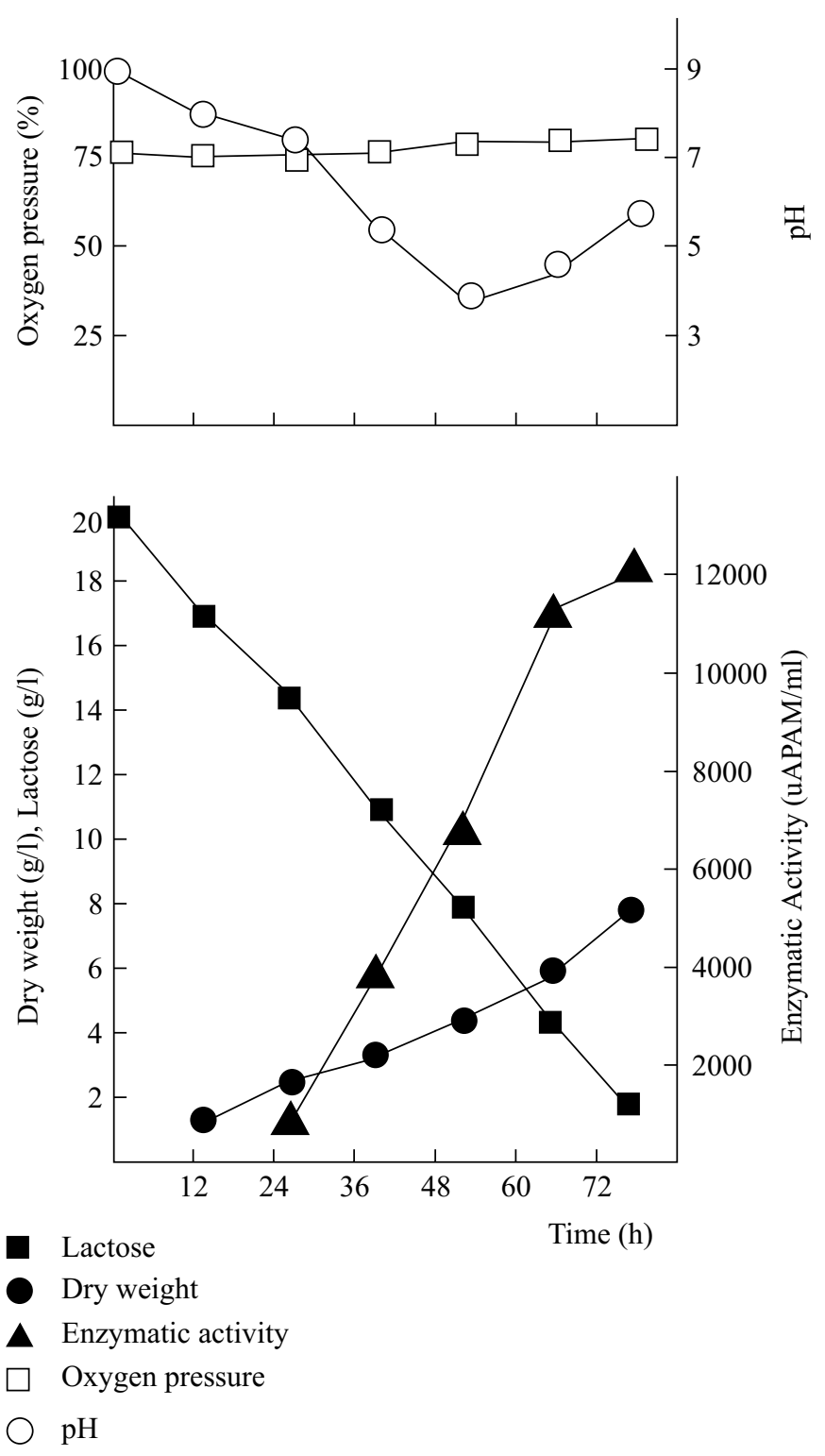

Figure 1. Production of proteases by Bacillus subtilis 3411, growing on seed meal amaranth $(20 \mathrm{~g} / \mathrm{L}$ medium $)$, in mechanically stirred fermentor (750 r.p.m. and 1 L/L.min). 
of protein were: aspartic acid, 2.8; serine, 2.3; glycine, 2.7; alanine, 1.3 and valine, 1.5 . Thus, in the presence of amaranth seed meal, there will not be a limitation for these amino acids as might occur in media obtained from traditional sources. Besides, the content of vitamins (mg/100 dry weight) was thiamine, 0.07; riboflavin, 0.19; folic acid, 43.80 and ascorbic acid, 4.90 (4).

Adding amaranth seed meal in concentrations higher than $20 \mathrm{~g} / \mathrm{L}$ did not produce an increase in enzyme production. This could be due either to the increase in the viscosity of the fermenting medium, limiting transference phenomena both of oxygen and metabolites, or to the fact that under such conditions, an inhibitory effect might occur due to an increase in amino acid concentration provided by amaranth.

If the results obtained in fermenters for similar oxygen dissolution rates are compared to those obtained in rotary shakers, 350 r.p.m., they will correspond, as expected, to equal rates of specific production. The highest enzyme values, obtained at 750 r.p.m., may be assigned to a greater oxygen availability in the culture medium where oxygen pressure was never below $30 \%$ of the saturation value as can be seen in Fig. 1.

However, higher agitation rates, 1000 r.p.m., increased the system's oxygen pressure but did not bring about production increase due, probably, at a high agitation rate, enzyme structure would be altered (12).

\section{ACKNOWLEDGEMENTS}

We thank the Facultad de Ciencias Exactas y Naturales, UNLPam, for finantial support.

\section{RESUMO}

\section{Obtenção de protease usando Bacillus subtilis 3411 e meio com farinha de semente de Amaranthus em diferentes condições de aeração}

Neste trabalho estudou-se a produção de proteases a partir de Bacillus subtilis 3411 cultivado em um meio no qual adicionou-se farinha de semente de Amaranthus cruentus como fonte de nutrientes e fatores de crescimento. As experiências foram realizadas em Erlenmeyers com agitador em fermentador de laboratório. Além disso, considerou-se a influência da aeração sobre a produção enzimática. A adição de amaranto em uma concentração de $20 \mathrm{~g} / \mathrm{L}$ produziu um aumento de $400 \%$ no nível de proteases. A aeração das culturas teve um efeito favorável até valores de 750 r.p.m. empregando um fluxo de ar de $1 \mathrm{~L} / \mathrm{L}$. min.

Palavras-chave: Proteases, Bacillus subtilis, amaranto, fermentação

\section{REFERENCES}

1. Balatti, A.P. Producción de enzimas. Primer Simposio Interamericano sobre Biotecnología de Enzimas, México, 1984, p.89-107.

2. Becker, R. Amaranth Oil: Composition, processing and nutritional qualities. In: O. Paredes-López (ed). Amaranth Biology, Chemistry and Thechnology. U.S.A., 1994, p.133-140.

3. Bressani, R. Grain amaranth. Its chemical composition and nutritive value. Proceeding of the Fourth National Amaranth Simposium. Perspectives on Production, Processing and Marketing, Minnesota, 1990, p.23-25.

4. Bressani, R. Composition and Nutritional Properties of Amaranth. In: O. Paredes-López (ed). Amaranth. Biology, Chemistry and Technology. U.S.A, 1994, p.185-206.

5. Chiasson, P.; Zamenhof, L.P. Studies of induction mutations by heat in spores of Bacillus subtilis. J. Microbiol., Vol. 12, 1966.

6. Cooper, C.M.; Ferston, G.; Miller, S.A. Gas Liquid Contactor. Ind. Eng. Chem., 36 : 504-509, 1944.

7. Covas, G. Revista Amarantos. Novedades e Informaciones. Estación Experimental Agropecuaria Anguil, INTA, Facultad de Agronomía, UNLPam, Argentina, 19: 1-12, 1995.

8. Kelly, C.; Fogarty, W. Microbial alcaline enzimes. Proc. Biochem., 7: 3-9, 1976.

9. Massucco, A.E.; Mazza, L.A.; Balatti, A.P. Obtención de preparados enzimáticos destinados a la depilación de pieles. Biotecnología de Enzimas. Primer Simposio Interamericano sobre Biotecnología de Enzimas, México, 1981, p.271-277.

10. Miller, G.L. Use of dinitrosalicylic acid reagent for determination of reducing sugar. Anal. Chem., 31 : 426-428, 1959.

11. Ravindran, V.; Hood, R.L.; Gill, R.J.; Kneale, C.R.; Bryden, W.L. Nutritional evaluation of grain amaranth (Amaranthus hypochondriacus) in broiler diets. A.F. Sci. Technol., 63 : 323-331, 1996.

12. Roychoudhury S.; Parulekar S.J.; Weigand W.A. Cell Growth and a-Amylase Production Characteristics of Bacillus amyloliquefaciens. Biotechnol. Bioeng., 33 : 197-206, 1988.

13. Ruzal, S.; Sanchez Rivas, J. Physiological and genetic characterization of the osmotic stress response in Bacillus subtilis. Can. J. Microbiol., 40 : 140-144, 1993.

14. Umbreit, W.W.; Burris R.H.; Sauffer J.S. The Warburg constant volume respirometer. In: Burgues Publishing Co. Manometric and Biochemical Techniques, U.S.A., 1972, p.1-17.

15. Zamenhof, S. Effects of heating dry bacteria and spores on their phenotype and genotype. Proc. Natl. Acad. Sci. 46 : 101-105, 1960. 